\title{
Kampung Wayang Dan Penguatan Materi Bahan Ajar Entreprenuer Sejarah
}

\author{
Andry Jadi Saputro, Soebijantoro \\ Program Studi Pendidikan Sejarah, FKIP, Universitas PGRI Madiun \\ Email: soebijantoro@unipma.ac.id
}

\begin{abstract}
Abstrak: Penelitian ini dilakukan dengan tujuan untuk mengkaji sejarah perkembangan kampung wayang di desa Kepuhsari dan potensinya sebagai penguatan materi bahan ajar entrepreneur sejarah bagi mahasiswa Program studi Pendidikan Sejarah Universitas PGRI MADIUN. Pendekatan yang dipergunakan dalam penelitian ini adalah dengan metode deskriptif kualitatif. Pengumpulan data dilakukan melalui observasi, wawancara, dan studi dokumentasi. Observasi dilakukan dengan pengamatan langsung secara non partisipasi dalam berbagai kegiatan masyarakat. Wawancara dilakukan baik secara terstruktur dengan daftar pertanyaan yang telah disistematisasikan berdasarkan gambaran awal yang didapat. Analisis data penelitian ini berpedoman pada langkah-langkah analisis data penelitian kualitatif yaitu: reduksi data, penyajian data, dan penarikan simpulan. Hasil penelitian menunjukkan bahwa 1) Seni tatah sungging wayang kulit di desa Kepuhsari sudah berlangsung sejak abad ke 18. Keterampilan yang diperoleh dari abdi dalem keraton Mangkunegaran menjadikan kualitas produk seni tatah sungging wayang kulit kulit di desa Kepusari diakui secara nasional. Sampai saat ini kerajinan tatah sunggih wayang kulit dinilai oleh masyarakat desa Kepuhsari lebih menjanjikan secara ekonomi dari pada bertani. Hingga tahun 2015 di Desa Kepuhsari ini telah memiliki 135 kepala keluarga yang menekuni usaha sebagai pengrajin wayang kulit sehingga oleh Pemerintah Kabupaten Wonogiri mendapat predikat sebagai Kampung Wayang. 2) Terdapat karakter entreprenuer yang dapat dibangun oleh mahasiswa melalui pembelajaran entrepreneur yaitu a) Berani mengambil resiko, b) Mandiri dan c) cerdas dalam melihat peluang ekonomi pada kondisi exciting yang menjadi kekuatan dalam usaha pengembangan wisata sehingga potret kampung wayang di desa Kepuhrejo dapat diaplikasikan dalam praktik entrepreneur khususnya potensi seni budaya yang bersinergi dengan pariwisata di Indonesia.
\end{abstract}

\section{Kata Kunci: Kampung wayang, bahan Ajar, Entreprenuer Sejarah}

Abstract: This research was conducted with the aim to examine the history of the development of the puppet village in Kepuhsari village and its potential as a strengthening of historical entrepreneurial teaching materials for students of the Historical Education Study Program at PGRI MADIUN University. The approach used in this research is descriptive qualitative method. Data collection is done through observation, interviews, and documentation studies. Observation was carried out by direct observation of non-participation in various community activities. The interview was conducted both in a structured manner with a list of questions that had been systematized based on the initial description obtained. Data analysis of this research is guided by the steps of analyzing qualitative research data, namely: data reduction, data presentation, and drawing conclusions. The results showed that 1) The art of wayang sungging shadow puppets in Kepuhsari village had been going on since the 18th century. The skills gained from the court servants of the Mangkunegaran palace made the quality of leather puppet sungging shadow puppets in Kepusari village nationally recognized. Until now, the craft of wayang sunggih wayang kulit is considered by the people of Kepuhsari village to be more economically promising than farming. Until 2015 in Kepuhsari Village, 135 families had been engaged in the business as wayang kulit craftsmen so that the Wonogiri District Government was awarded the Wayang Village. 2) There is an entrepreneurial character that can be built by students through entrepreneurial learning, namely a) Daring to take risks, b) Independent and c) smart in seeing economic opportunities in exciting conditions that are a force in tourism development efforts so that the portrait of the puppet village in Kepuhrejo village can be applied in the practice of entrepreneurs, especially the potential of art and culture that synergizes with tourism in Indonesia.

\section{Keywords: Puppet Village, Teaching material, Entrepreneur History}




\section{Pendahuluan}

Kebudayaan merupakan hasil cipta, rasa, karsa manusia, oleh karena itu kebudayaan mengalami perubahan perkembangannya sejalan dengan perkembangan manusia itu.Perkembangan tersebut dimaksudkan untuk kepentingan sendiri, karena kebudayaan diciptakan oleh dan untuk manusia (Setiadi, 2007). Salah satu wujud kebudayaan adalah seni budaya wayang. Wayang merupakan warisan budaya masa lampau yang hidup dalam masyarakat sebagai alat pemersatu kesatuan.

Wayang merupakan kesenian yang sangat populer. Pada masa pemerintahan raja-raja di Jawa wayang digunakan sebagai sarana hiburan bagi rakyat. Raja-raja di Jawa pada saat itu menepatkan wayang sebagai kesenian yang mempunyai nilai kreasi yang sangat tinggi. Dalam beberapa hal, para raja mengambil bagian dari kesenian wayang yang berupa tari-tarian sebagai simbol keagungan kerajaan (Lisbijanto,2013).

Bagi masyarakat Jawa, wayang sebenarnya tidak bisa lepas dari kepercayaan yang hidup dalam masyarakat, terutama masyarakat pedesaan. Dalam seni pertunjukan wayang tidak jarang kita jumpai pantangan atau larangan dalam pentas lakon atau cerita tertentu.. Ada anggapan yang hidup dalam masyarakat bahwa lakon Bharatayuda tidak boleh dipentaskan dalam upacara perayaan perkawinan (lisbijanto, 2013:53). Sehingga wayang dapat digunakan sebagai pemersatu dan kesatuan bangsa Indonesia yang memiliki beragam suku, ras, budaya dan lain sebagainya. Menurut Daru Suprapto (dalam jati Widagdo. 2019) dijelaskan bahwa Wajang adalah salah satu seni kebudayaan yang merangkum berbagai macam bidang seni: ukir / pahat, sungging / lukis, gerak / tari, karawitan / musik, vokal maupun instrumental, dan sastra; memuat isi padat dan bermutu penuh, mencakup segi religi dan filsafat, etika dan estetika, psikologi dan pedagogik.

Dengan fungsi pedagogic tersebut, serta apabila dikaitkan dengan teori dari Koentjaraningrat, maka wayang adalah salah satu unsur kebudayaan Jawa, yang diciptakan dalam rangka mengedukasi masyarakat guna mencapai kesejahteraan, keselamatan dan kebahagiaan hidup lahir dan batin. Sedemikian dalam dan luas substansi wayang dalam upaya untuk memahami kehidupan manusia secara holistik.

Maka oleh badan dunia UNESCO ditetapkan sebagai warisan dunia serta sebagai World Masterpiece of Oral and Intangible Heritage of Humanity pada tahun 2003. Bahkan UNESCO pernah secara intens mensosialisasikan dan menghimbau kepada negara-negara anggota PBB untuk melakukan inventarisasi harta budaya tak benda (Intangible Cultural Heritage) atau 
disingkat ICH. Hal itu disebabkan oleh kekhawatiran bahwa harta budaya dunia yang tak ternilai harganya itu akan menghilang satu-persatu diganti produkproduk budaya global yang tidak mengenal batas dan identitas. Saat ini eksistensi wayang sebagai salah satu wujud seni budaya menjadi penting ketika pemerintah Indonesia melalui kementerian pariwisata menggalakkan kekayaan dan keragaman budaya sebagai aset yang tidak ternilai.

Bahkan pada tahun 2017, World Economic Forum (WEF) telah menempatkan Indonesia pada peringkat ke-42dalam indeks daya saing pariwisata dan perjalanan (Travel and Tourism Competitiveness Index) dengan nilai 4, 2 (Klaus Schwab dalam Adhiningasih Prabhawati 2018). Peringkat tersebut meningkat dari tahun sebelumnya yaitu Indonesia di peringkat ke-50. Indeks daya saing Indonesia melesat naik 8 poin, dari posisi 50 besar dunia ke peringkat ke42.

Dari penjelasan tersebut diatas, Pemerintah Indonesia mengajak semua elemen masyarakat untuk ikut serta menggalakkan dinamika pariwisata melalui optimalisasi asset wisata yang dimilikinya. Salah satu diantaranya adalah keikutsertaan kelompok masyarakat di Desa Kepuhrejo Kecamatan Manyaran Kabupaten Wonogiri yang menjadikan wilayah tempat tinggal mereka sebagai salah satu sentra kunjungan wisata yang dikemas dengan nama kampung wayang. Kebijakan pariwisata nasional dengan jelas menetapkan keanekaragaman budaya di Indonesia sebagai salah satu fokus pengembangannya. Hal ini ditegaskan dalam Undang-Undang Nomor 10 Tahun 2009 tentang budaya merupakan salah satu sumber daya pembangunan pariwisata nasional. Bahkan dalam Undang Undang Nomor 10 Tahun 2009 juga menjelaskan bahwa kebudayaan nasional yang sangat beragam, sangat strategis sebagai basis pengembangan pariwisata.

Damanik (dalam Adhiningsih $P$. 2018) mengemukakan bahwa dalam Undang Undang tersebut diatas bermakna luas. Pertama, budaya dalam bentuknya yang tangible dan intangible memerlukan pemaknaan baru dalam arti pemanfaatan untuk menjadi daya tarik pariwisata. Hal ini berarti terdapat upaya diversifikasi yang tinggi, keaslian dan keunikan pada unsurunsur budaya Indonesia yang menjadikannya sebagai daya tarik yang tidak hanya semata-mata memiliki kultural tetapi juga nilai ekonomi dan nilai kemanusiaan.

Kedua, budaya sebagai kekayaan bangsa perlu dikembangkan dan dilestarikan untuk kepentingan generasi yang akan datang sekaligus sebagai jati diri dan identitas bangsa dalam pergaulan internasional. Dengan demikian mengacu dari penjelasan tersebut diatas Nampak bahwa keanekaragaman budaya yang dikemas dalam aktivitas pariwisata dapat 
ditumbuh kembangkan melalui strategi menumbuhkan jiwa entrepreneur di perguruan tinggi. Saat ini perguruan tinggi seakan berlomba membangun atmosfir kewirausahaan agar dapat mewujudkan perguruan tingginya sebagai Entrepreneurial Campus. Salah satu faktor adalah belum terserapnya lulusan perguruan tinggi di dunia kerja. Artinya bahwa output yang dihasilkan perguruan tinggi saat ini adalah bukan sebagai opportunity creator melainkan output yang bermental waiting for the opportunity comes.

Terkait dengan hal itu Sanjaya (2010) mengatakan bahwa salah satu peran penting kurikulum adalah mewujudkan peranannya yang kritis dan evalusi terhadap nilai-nilai dan budaya yang hidup dalam masyarakat senantiasa berubah dan perlu disesuaikan dengan kondisi yang terjadi pada masa sekarang. Kurikulum entreprenuer di perguruan tinggi saat ini belum sepenuhnya mampu untuk mewujudkan pengetahuan yang riil bagaimana memunculkan ide atau gagasan bisnis.

Bahkan Mansheng Zhou dan Haixia Xu (2012) mengatakan bahwa salah satu problem pembelajaran entrepreneur di perguruan tinggi adalah belum tersedianya bahan ajar yang berisikan keselerasan dan kesinambungan antara materi perkuliahan dengan kebutuhan di lapangan serta melibatan aktif dari semua pemangku kepentingan termasuk mengembangkan kerangka kebijakan untuk kewirausahaan utama dalam pendidikan yang lebih tinggi. Meskipun pelakasanaan pengajaran entrepreneur di perguruan tinggi masih menjadi perdebatan yaitu disatu sisi berpendapat bahwa pendidikan kewirausahaan umumnya berisi materi dan aktivitas yang berhubungan dengan membangun sikap mental kewirausahaan, melatih keterampilan berkomunikasi, membangun jejaring dan menyusun rencana bisnis yang berorientasi pada keuntungan.

Di sisi lain berpendapat bahwa program studi atau Fakultas tidak mendidik mahasiswa atau lulusannya menjadi pengusaha, dan fakultas atau program studi yang paling sesuai yang justru mewajibkan mahasiswanya untuk mengikuti mata kuliah kewirausahaan seperti fakultas ekonomi. Namun apabila mengacu pada Peraturan Pemerintah No. 17 tahun 2010 tentang pengelolaan dan penyelenggaraan Pendidikan menegaskan bahwa salah satu tujuan Pendidikan Tinggi adalah bertujuan membentuk insan yang kritis, kreatif, inovatif, mandiri, percaya diri dan berjiwa wirausaha.

Dengan demikian merupakan kewajiban kepada perguruan tinggi untuk menyiapkan lulusan dengan profesi apapun agar dibekali dengan beberapa karakter antara lain adalah berjiwa wirausaha. Terkait dengan hal itu Gualdron Morales (dalam Nebosja Zakic, 2012) menjelaskan fakta menunjukkan bahwa terdapat 
sinyalemen kegagalan dalam proses pendidikan dewasa ini yang berakibat bahwa jenjang pendidikan seseorang tidak berpengaruh terhadap jiwa dan perilaku seseorang untuk menjadi seorang entrepreneur. Dalam penelitian yang telah dilakukan terungkap bahwa serapan lulusan program studi Pendidikan sejarah Universitas PGRI MADIUN (eks IKIP PGRI MADIUN) terhitung sejak tahun 2012 hingga 2015 untuk menekuni profesi sebagai seorang entrepreneur sangat rendah yaitu 0, 82 \% (Soebijantoro, 2015).

Kemudian dalam penelitian lanjutan terungkap pula bahwa keengganan tersebut juga disebabkan karena rendahnya motivasi yang dikarenakan 1). Mahasiswa beranggapan bahwa mata kuliah entrepreneur adalah mata kuliah wajib yang harus ditempuh. Artinya sifat wajib yang mendorong mahasiswa untuk memprogram mata kuliah tersebut, 2). Materi entrepreneur yang diberikan kepada mahasiswa pada umumnya sama untuk semua program studi khususnya di Fakultas Keguruan dan Ilmu Pendidikan,

3). Terbatasnya bahan bahan ajar yang lebih spesifik menekankan bidang garapan bagi lulusan program studi Pendidikan sejarah (Soebijantoro. 2018). Apabila hal ini dikaitkan dengan pedoman penulisan modul yang dikeluarkan oleh kementerian Pendidikan dan Kebudayaan Dirjen Guru dan Tenaga Kependidikan Tahun 2015 bahwa bahan ajar harus memiliki beberapa karakteristik, yaitu self instructional, self contained, stand alone, adaptive, dan user friendly. Penjelasan dari pedoman tersebut diatas khususnya karakter self instructional, dimaksudkan agar bahan ajar dapat membuat siswa mampu membelajarkan diri sendiri dengan bahan ajar yang dikembangkan. Untuk itulah maka di dalam bahan ajar harus terdapat tujuan yang dirumuskan dengan jelas, baik tujuan akhir maupun tujuan antara.

Selain itu, dengan bahan ajar akan memudahkan siswa belajar secara tuntas dengan memberikan materi pembelajaran yang dikemas ke dalam unit-unit atau kegiatan yang lebih spesifik. Salah satu implementasi program studi dalam upaya meningkatkan kualitas pembelajaran adalah penguatan bahan ajar entrepreneur sejarah yang dapat memberikan wawasan serta motivasi mahasiswa untuk berani menekuni profesi sebagai seorang entrepreneur yaitu dibidang pariwisata khsususnya pariwisata sejarah dan budaya.

Secara khusus kajian pariwisata sejarah dan budaya dalam konteks entrepreneur adalah difokuskan di wilayah kota dan Kabupaten Madiun. Penguatan diperlukan untuk memberikan motivasi bagi mahasiswa. Konsep penguatan (reinforcement) merupakan salah satu ketrampilann dalam teori koneksinisme (connectionism) yaitu teori yang ditemukan dan dikembangkan oleh Edward L 
Thomdike bahwa belajar adalah hubungan antara stimulus dan respon, jika sebuah respon menghasilkan efek yang memuaskan, maka hubungan antara stimulus dan reson akan semakin kuat, begitu juga sebaliknya. Dengan melalui penguatan ini diharapkan dapat dipergunakan oleh guru maupun dosen untuk memberikan motivasi kepada sisiwa maupun mahasiswa untuk lebih berani menekuni bidang entrepreneur.

Kawasan Kota maupun kabupaten Madiun memiliki potensi pariwisata yang terus dikembangkan. Baik terhadap obyek peninggalan sejarah maupun aktifitas seni budaya. Terutama sekali memberikan wawasan kepada mahasiswa terkait peluang peluang ekonomi yang dapat dikembangkan. Salah satu upaya pengayaan materi bahan ajar tersebut adalah dengan menambahkan potensi kampung wayang di kabupaten Wonogiri yang melalui pendekatan entrepreneur mampu berkembang sebagai destinasi unggulan di Jawa tengah.

Meskipun lokasi kampung wayang berada di Propinsi Jawa Tengah, namun kajian sejarah berdirinya kampung wayang dapat dipergunakan oleh mahasiswa untuk menginspirasi pengembangan budaya local yang memiliki peluang ekonomi khususnya disektor pariwisata. Untuk itu dalam penelitian ini akan dibahas potensi kampung wayang di desa Kepuhsari yang dapat dipergunakan sebagai pengayaan bahan ajar entrepreneur sejarah bagi mahasiswa program studi Pendidikan sejarah. Dari visi dan misi Program studi Pendidikan sejarah Universitas PGRI MADIUN diatas, maka menurut Cahyo BU (2009) dalam konteks entrepreneur sejarah, diharapkan output yang dihasilkan harus menghasilkan lulusan yang memiliki kemampuan life skill yaitu kemampuan mengidentifikasi kebutuhan dan peluang, merancang desain, evaluasi pasar, melakukan rencana dan aksi, penjualan, evaluasi proses, penggunaan teknologi informasi dan lain-lain.

Ditegaskan pula dalam konteks entreprenuer sejarah, maka seseorang yang terjun dalam bidang itu adalah seorang dengan jiwa dan semangat entrepreneur yang mampu menghadirkan produk-produk hasil kajian kesejarahan yang bisa diterima oleh masyarakat. Terdapat banyak peluang ekonimi yang dapat dibangun oleh sarjana Pendidikan sejarah. Menurut Schumpeter (dalam Dilwyn Porter \& Wray Vamplew, 2019) dikatakan bahwa dalam sejarah kewirausahaan menunjukkan bahwa kesuksesan pelaku usaha tidak lepas dari upaya mempelajari inovasi dalam sejarah sosial ekonomi.

Artinya tulisan maupun analisis seorang sejarawan sangat berharga dalam dunia usaha sebab dengan bekal intuisi nya dapat menjelaskan fenomena yang hanya dapat diidentifikasi setelah peristiwa sejarah itu terjadi dan sebuah fenomena 
sangat baik untuk dipelajari sebagai sebuah elemen penting dalam proses perubahan industri dan ekonomi.

\section{Metode}

Penelitian ini dilakukan di Desa Kepuhsari, Kecamatan Manyaran Kabupaten Wonogiri dan di Program studi pendididkan Sejarah Universitas PGRI MADIUN. Adapun pendekatan yang dipergunakan dalam penelitian ini adalah diskriptif kualitatif. Data diperoleh melalui observasi, wawancara, dan studi dokumentasi. Observasi dilakukan dengan pengamatan langsung secara non partisipasi dalam berbagai kegiatan pelaku seni wayang..

Wawancara dilakukan baik secara terstruktur dengan daftar pertanyaan yang telah disistematisasikan berdasarkan gambaran awal yang terkait dengan fenomena yang diteliti. Adapun nara sumber penelitian ini adalah anggota masyarakat kampung wayang, seniman, pelaku bisnis pariwisata Dosen pengampu mata kuliah entrepreneur serta mahasiswa maupun alumni.

Pemilihan informan dilakukan secara selektif berdasarkan kebutuhan data. Selain mengumpulkan data primer, juga mengumpulkan data sekunder. Data tersebut adalah meliputi profil pelaku seni wayang, data-data wilayah secara umum, dan data mengenai wisata di lokasi penelitian dari sumber buku dan literature lain, serta penelusuran berbagai informasi yang dipublikasikan dalam media elektronik maupun cetak. Peneliti juga mengumpulkan data yang bersifat visual dalam bentuk foto dan video. Adapun analisis data penelitian ini berpedoman pada langkah-langkah analisis data penelitian kualitatif yang dikemukakan oleh Moleong (2011), yaitu: (1) reduksi data, (2) penyajian data, dan (3) penarikan simpulan. Reduksi data meliputi proses pemilihan, pemfokusan, penyederhanaan, pengabstraksian, pentransformasian data, dan pengategorian untuk memudahkan pengorganisasian data.

Dari proses itu, penyajian data dilakukan untuk disusun secara sistematis dengan memperlihatkan kaitan alur data dan menggambarkan apa yang sebenarnya terjadi sehingga memudahkan peneliti untuk menarik simpulan. Penarikan simpulan dilakukan sejak tahap pengumpulan data dengan cara mencatat dan memaknai fenomena yang menunjukkan keteraturan, kondisi yang berulang-ulang, serta pola-pola atau model yang dominan.

\section{Hasil Dan Pembahasan}

Secara adminsitratif Desa Kepuhsari terletak di Kecamatan Manyaran Kabupaten Wonogiri. Topologi Desa Kepuhsari sebagian besar berupa tekstur tanah yang kering, tandus, berbatu-batu, dan berbukitbukit. Sedangkan data demografi menunjukkan jumlah penduduk Desa Kepuhsari, padab tahun 2016 berjumlah 
6.094 orang, yang terdiri dari laki-laki 3.033 dan wanita 3.061 dengan sebagaian besar penduduk bermata pencaharian sebagai petani. Dari data topologi dan demografi tersebut, masyarakat desa Kepuhsari menyadari tidak sepenuhnya tidak mengandalkan sector pertanian untuk menopang perekonomian mereka. Untuk itulah diperlukan terobosan guna melihat peluang ekonomi, salah satu diantaranya adalah memanfaatkan potensi seni budaya yang dimiliki qwarga masyarakat desa Kepuhsari.

Menurut Soetarno seorang tokoh perajin wayang kulit desa Kepuhsari dikatakan bahwa munculnya kesenian wayang khususnya wayang kulit diawali oleh Ki Dino Hadi Carito dan Gunarto Prawiro. Mereka memiliki murid bernama Wagiman dan Karso. Mereka mendapat keahlian dalam mencari atau memilih jenis kulit yang baik untuk dijadikan wayang, menatah kulit, melukis wayang, dan seni pendalangan wayang.

Terkait dengan hal itu Prijanto (2018) menjelaskan pula desa ini dikenal sebagai rumahnya para pembuat wayang kulit berkualitas tinggi. Khususnya karya ahli tatah sungging Kepuhsari yang sampai saat ini masih menjadi pilihan utama para dalang dan kolektor. Dijelaskan pula oleh Prijanto bahwa tatah sungging di Kepuhsari diyakini sudah ada sejak abad 18 lalu yang diperoleh dari seorang abdi dalem Keraton Mangkunegaran. Fakta bahwa produk wayang kulit dengan tata sungging kualitas tinggi, menyebabkan masyarakat beralih menjadi perajin wayang yang lebih menjanjikan secara ekonomi dari pada bertani. Secara turun temurun mereka belajar dari nenek moyang mereka membuat wayang kulit. Tercatat hingga tahun 2015 di Desa Kepuhsari ini sudah memiliki 135 kepala keluarga yang melakoni usaha sebagai pengrajin wayang kulit.

Oleh karena itu Desa kepuhsari oleh Pemerintah Kabupaten Wonogiri mendapat predikat sebagai Kampung Wayang. Untuk tetap menjaga eksistensi keberadaan wayang kulit di Desa Kepuhsari, masyarakat disana menggunakan kesenian wayang sebagai hiburan ketika ada acara kampung/hajatan (Lilyk Eka Suranny.2018). Dengan ditetapkannya sebagai kampung wayang serta menjadi salah satu destinasi wisata pilihan di jawa Tengah khususnya di Wonogiri.

Maka pada tahun 2012 pengelola melakukan sosialisasi khususnya, membekali masyarakat Desa Kepuhsari dalam menerima dan melayani para wisatawan yang ingin berkunjung ke Desa Kepuhsari dengan baik dan baru pada tahun 2013 desa kepuhsari mulai menerima wisatawan asing. Terdapat upaya masyarakat untuk mempertahankan predikat sebagai kampung wayang antara lain 1) Mendirikan sanggar-sanggar seni tata sungging. 2) mengadakan seminar 
kebudayaan 3) Pertunjukan seni kerawitan pada hari kamis dan malam minggu, 4) Pagelaran wayang kulit setiap malam pertama bulan suro untuk melakukan bersih desa, 5) Membuka website tentang kampung wayang seperti www.wayangvillage.com. 6) Membuka homestay bagi wisatawan yang ingin lebih lama dalam menikmati layanan masyarakat desa Kepuh rejo. Dalam konteks jenis pariwisata, maka Kawasan wisata kampung wayang termasuk jenis destinasi wisata alternatif.

Artinya tidak hanya destinasi yang menyajikan seni budaya wayang kulit saja, akan tetapi sudah merambah pada produk wisata edukatif seperti wisata untuk belajar membuat wayang maupun wisata perkebunan kopi dan wisata peternakan, sehingga pengunjung dapat berinteraksi dengan penduduk setempat. Hal ini seperti yang dikatakan oleh Holden (dalam Eirini Triarchi, 2003) bahwa pariwisata alternatif merupakan wisata berkelanjutan yang dekat dengan lingkungan alam seperti vegetasi, habitat hewan, dan lahan pertanian serta muncul kesadaran untuk menjaga lingkungan hidup.

Terkait dengan potensi pengembangan wisata eduatif tersebut diatas, Lilyk Eka Suranny (2018) dalam penelitiannya mengungkapkan bahwa terdapat potensi yang menjadi modal dasar bagi masyarakat desa Kepuhrejo. Modal dasar itu yaitu kondisi exciting yang menjadi kekuatan dalam usaha pengembangan wisata yaitu keindahan alam, potensi sumberdaya manusia dan potensi sumberdaya budaya. Hal ini bisa kita saksikan dengan adanya keindahan air terjun "Banyu Nibo" serta pemandangan Kawasan pertanian dan pegunungan ini berpotensi dijadikan wisata alam maupun wisata pendidikan.

Wisata alam yang memperlihatkan keindahan air terjun dan lingkungan sekitarnya yang masih alami serta wisata pendidikan pertanian yang mengajarkan para wisatawan bercocok tanam/budidaya pertanian maupun membuat wayang melalui potensi sumberdaya manusia yang memiliki yaitu seni tatah sungging (seni kerajinan membuat wayang kulit). Kondisi exciting lain yang dimiliki oleh Kampung Wayang Kepuhsari adalah sambutan yang ramah masyarakat dalam memberikan pelayanan kepada para pengunjung.

Setidaknya tingkat kepuasan dari pengunjung dapat dinilai salah satunya dari pelayanan yang didapatkan saat melakukan kunjungan wisata. Seperti yang diungkapkan oleh Sularjo seorang pengrajin wayang kulit bahwa jumlah pengunjung dari tahun ke tahun semakin meningkat, bahkan keterampilan membuat wayang sudah masuk menjadi muatan lokal di SMP. Dari hasil temuan tersebut diatas peneliti melihat bahwa kajian Kawasan kampung wayang Kepuhsari dapat dipergunakan sebagai pengayaan materi bahan ajar 
entrepreneur sejarah pada program studi Pendidikan Sejarah Universitas PGRI MADIUN. Adapun alasan pentingnya pengayaan tersebut antara lain, Pertama, adalah berdasarkan hasil penelitian awal menunjukkan bahwa materi bahan ajar entrepreneur bagi mahasiswa Program Studi Pendidikan Sejarah untuk saat ini belum sepenuhnya membahas bidang garapan bagi mahasiswa maupun alumni program studi Pendidikan Sejarah (Soebijantoro, 2018).

Kedua, terdapat karakter entreprenuer yang dapat dibangun oleh mahasiswa melalui pembelajaran entrepreneur yaitu 1) Berani mengambil resiko, 2) Mandiri dan 3) cerdas dalam melihat peluang ekonomi. Potret kampung wayang di desa Kepuhrejo dapat diaplikasikan dalam praktik entrepreneur khususnya potensi seni budaya yang bersinergi dengan pariwisata.

Ketiga, adalah Bekal materi pada pembelajaran Sejarah kebudayaan Indonesia sangat mendukung mahasiswa dalam mengkaji peluang ekonomi pada potensi seni budaya yang ada di Indonesia, Dinamika kampung wayang di desa Kepuhsari menunjukkan kepada mahasiswa bagaimana masyarakat desa Kepuhsari maupun pelaku pariwisata disana melihat potensi yang dimiliki baik sumber daya alam maupun sumber daya manusia menjadi sebuah peluang ekonomi yang sangat besar. Keempat, spirit entrepreneur yang ditunjukkan oleh masyarakat desa, pelaku seni maupun pariwisata telah menunjukan hasil yang baik. Berdasarkan data dari Pemerintah Desa Kepuhrejo pada tahun 2013 mencatat bahwa desa tersebut telah dikunjungi wisatawan internasional dari 28 negara. Dengan melihat antausias wisatawan yang datang ke Kampung Wayang Desa Kepuhsari ini maka masing msing pengrajin mendirikan sanggarsanggar seni yang melayani wisatawan untuk. Kelima. yang dipergunakan untuk pengembangan sarana dan prasarana kampung wayang yang belum tersedia.

Kelima, dengan demikian sebagai tempat yang diharapkan dapat memberikan kontribusi ekonomi, Pariwisata merupakan sektor ekonomi yang terbukti mampu mengentaskan kemiskinan di daerah karena dalam pengelolaan pariwisata akan memiliki trickle down efect bagi masyarakat lokal (Rohim, 2013). Artinya kegiatan ekonomi yang lebih besar diharapkan dapat memberikan efek terhadap kegiatan ekonomi di bawahnya yang memiliki lingkup yang lebih kecil.

Untuk itu sangat diperlukan usaha keras dari berbagai pihak untuk mewujudkan kawasan kampung wayang sebagai obyek pariwisata. Sebagai salah satu Kawasan destinasi unggulan, saat ini masyarakat desa kepuhsari dapat menerima manfaatnya. Manfaat yang dapat dilihat adalah a) Produk wayang kulit Desa Kepuhsari ini terjual dibeberapa kota di 
Indonesia. b) Tersedianya jasa transportasi yang disediakan warga setempat bagi wisatawan yang menginap di rumah warga.

c) Muncul berbagai usaha-usaha baru antara lain rumah makan, counter Handphone, d) Showroom wayang yang menjual aneka souvenir khas para pengrajin.

\section{Kesimpulan}

Dari hasil temuan dan pembahasan maka dapat disimpulkan bahwa bahwa 1) Seni tatah sungging wayang kulit di desa Kepuhsari telah berlangsung sejak abad ke 18. Keterampilan yang diperoleh dari abdi dalem keraton Mangkunegaran menjadikan kualitas produk seni tatah sungging wayang kulit kulit di desa Kepusari diakui secara nasional. Sampai saat ini kerajinan tatah sunggih wayang kulit dinilai oleh masyarakat desa Kepuhsari lebih menjanjikan secara ekonomi dari pada bertani.

Hingga tahun 2015 di Desa Kepuhsari ini telah memiliki 135 kepala keluarga yang menekuni usaha sebagai pengrajin wayang kulit sehingga oleh Pemerintah Kabupaten Wonogiri mendapat predikat sebagai Kampung Wayang. 2) Terdapat karakter entreprenuer yang dapat dibangun oleh mahasiswa melalui pembelajaran entrepreneur yaitu a) Berani mengambil resiko, b) Mandiri dan c) cerdas dalam melihat peluang ekonomi pada kondisi exciting yang menjadi kekuatan dalam usaha pengembangan wisata sehingga potret kampung wayang di desa Kepuhrejo dapat diaplikasikan dalam praktik entrepreneur khususnya potensi seni budaya yang bersinergi dengan pariwisata di Indonesia.

\section{Daftar Pustaka}

Cahyo, B. U. (2009). Pengembangan Kurikulum Sejarah Berbasis Entreprenuership.

Dilwyn Porter \& Wray Vamplew. (2018). Entrepreneurship, Sport, and History: An Overview. The International Journal of the History of Sport. 35(78), 626-640.

Djiwandono, S. E. W. (1989). Psikologi pendidikan. Jakarta: P2LPTK

Https://www.tandfonline.com/doi/full/10. 1080/09523367.2018.1544126

Lisbijanto, H. (2013). Wayang. Yogyakarta: Graha Ilmu

Makalah Lokakarya Nasional Pengembangan Kurikulum Sejarah Berbasis Skill dan Entrepreneurship untuk Peningkatan Kompetensi Lulusan 3 Juni 2009. Semarang: Fakultas Ilmu Budaya UNDIP.

Milles, M. B., \& Huberman, A. M. (1992). Analisis Data Kualitatif. Jakarta: Universitas Indonesia

Prabhawati, A. (2018). Upaya Indonesia dalam Meningkatkan Kualitas Pariwisata Budaya Melalui Diplomasi Kebudayaan. Journal of Tourism and Creativity, 2(2).

Prijanto. (2017). Desa Wisata Budaya Wayang Kulit Jawa Sebagai Destinasi Wisata Minat Khusus dan Komoditas Pariwisata Indonesia. Journal of Indonesian Tourism and Policy Studies, 2(1), 43-59.

Setiadi, E. M. (2007). Ilmu Sosial dan Budaya Dasar. Jakarta : Kencana

Soebijantoro, \& Hidayatullah, F., \& Hariyanto, S., \& Hariyati, S. (2018). Penguatan Bahan Ajar Entrepreneur Sejarah Berbasis Electronic Publication Melalui Analisa 
kebutuhan Mahasiswa dan Stake Holder. Proceedings International Conference on Teaching and Education (ICoTE), 2.

Soebijantoro. (2015). Pengajaran Entreprenuer (Studi Kasus Pada Program Studi Pendidikan Sejarah IKIP PGRI MADIUN). Procceding Contribution of History For Social Sciences and Humanities. Malang: FIS UNM

Stewart, M. (2015). Why University need an entreprenuersial Spirit. The World Economic Forum https://www.weforum.org/agenda/ 2015/05/why-universities-need-anentrepreneurial-spirit/

Suranny, L. E. (2018). Pengembangan Wisata di kampung wayang Kepuhsari. Kecamatan Manyaran Kab. Wonogiri berbasis SWOT. Wonogiti: Jurnal Litbang Sukowati, $1(2)$.

Widagdo, J. (2019). Struktur Wajah, Aksesorie sert Pakaian wayang Kulit Purwo. Jepara: Jurnal Suluh, 1(2).

Widya, I. G. (1991). Sejarah Lokal Suatu Persepktif Dalam Pengajaran Sejarah. Bandung : Angkasa

Wina, S. (2009). Strategi Pembelajaran Berorientasi Standar Proses Pendidikan. Jakarta : Kencana

Zakic, N., \& Stammatovic, M., \& Stevovic, S. (2012). Necessity of entrepreneurship education: A research among entreprenuers and potential entrepreneur in Serbia. African Journal of Bussiness management, 6(9), 3173-3180. https://doi.org/10.5897/AJBM11.33 